\title{
Study on the Training Mode of Civil Engineering
}

\author{
Jian Tang \\ Nanchang Institute of Technology \\ Nanchang, China \\ 176024108@qq.com
}

\author{
Hua Luo \\ Nanchang Institute of Technology \\ Nanchang, China \\ 705413069@qq.com
}

\begin{abstract}
This paper summarizes the formation development and law of the subject and combine the social requirements of civil engineering professionals in our country's economic and social development. This paper explores the existing problems in the education of civil engineering in colleges and universities in our country and proposes "comprehensive, learning, open, internationalization" of talent training mode, which has a strong reference to the reform of education and teaching of similar majors in colleges and universities in our country and has a great enlightenment on the research and practice of educational theory in the new era.
\end{abstract}

Keywords_talents training mode; comprehensive; learning; internationalization; openness

\section{INTRODUCTION}

Undergraduate education is the basic task of college talents training, and the training mode of undergraduate professional talents is the blueprint of undergraduate talent cultivation. With our country higher education reform from the management system reform to the deepening of structural adjustment of subjects, the institutions of higher learning must carry out the reform of undergraduate professional talents training mode so as to cultivate the high-quality and innovative talents needed by social development ${ }^{[1]}$. With the deepening of the reform of our country's higher education from the reform of the management to the disciplinary structure, the institutions of higher learning must carry out the reform of undergraduate professional personnel training mode so as to cultivate the high-quality and innovative talents needed by social development. The reform of undergraduate professional talents training mode is the inevitable requirement of the reform of higher education in our country due to knowledge economy and economic globalization and the popularization of higher education ${ }^{[2]}$.

According to the American Society of Engineering Education (ASEE) distinction, civil engineering is one of the top ten engineering disciplines. According to the Catalog of Regular Undergraduate Colleges and Universities distributed by the Ministry of Education in July 1998, civil engineering is also one of the most advanced subjects in history. However, even with a long history of disciplines, with the improvement of marketization degree, market also puts forward new requirements for civil engineering talent, which brings the impact of civil engineering training and education mode. Facing world, future and market, updating training model design and focus on cultivating a solid foundation of knowledge, a higher quality and strong ability's international engineering talent, which is both the starting point of education

This work was financially supported by the Jiangxi teaching Reform and Researching Program of Higher Education(JXJG-15-25-2). and teaching reform, will also be the most powerful judgment of the reform outcome.

Based on the social requirements of civil engineering professionals in our country's economic and social development, this paper explores the existing problems in the education of civil engineering major in colleges and universities in our country, puts forward a new mode of personnel training, which has a great effect on the reform of education and teaching of similar majors in our country and has a strong reference for the new era of educational theory research and practice have a greater enlightenment.

\section{CONSTRUCTION OF CIVIL ENGINEERING PROFESSIONAL TRAINING MODE}

Civil engineering for the purpose of cultivating engineering national construction required excellent senior engineering and technical personnel, the professional is not only practical, but also relates to the field of engineering disciplines, wide range, high requirements for students of coordination, organization, management and decision-making ability, with the rapid development of science and technology and global economic integration. The industry of civil engineers international vision and international competitiveness are increasingly high requirements ${ }^{[3]}$

\section{A. The definition of talent training mode}

In order to construct scientific and reasonable talent cultivation mode, it is necessary to clarify the connotation of talent cultivation and its constituent elements. The process of talent cultivation is a complete and complicated process of multiple factors, and the relationship between each factor in the process of talent cultivation form a structure. The talent training mode is a kind of relatively stable, systematic and theoretical model that is formed under the guidance of certain education thoughts.

The cultivation of talents should be composed of five factors which are related to each other and restrict each other: the guiding thoughts is the theoretical basis and basis for the establishment of talent training mode; The training target is the standard and requirement of talent training, which is the core of the construction of talent cultivation mode, and it has the adjustment, regulation and guiding effect on talent cultivation activities; The training program is based on certain guiding thoughts, and the teaching content is selected for the completion of the training goal, so as to form a series of courses, which constitute a certain course structure; Training process is the process of talents training to meet the law of 
physical and mental development of students and the laws of education; Training strategies, is to complete the training objective and the implementation of teaching to adopt a series of measures, methods and means, including classroom teaching and practical teaching, various systems and measures of teaching management and specific operational requirements; Teaching evaluation is based on a certain principle established with the training objectives, training programs, training process, training strategies to adapt to the evaluation methods and standards in order to complete the implementation of training objectives.

The recognition of talents training mode the relationship its several elements is conducive to dynamically grasping the law of the process of talents training, formulating scientific and reasonable talents training mode, overcoming the blindness of talents training, enhancing controllability and increasing talents training's quality.

\section{B. The current problems of Civil engineering talent training mode}

The current civil engineering talent training model has the problems of obsolete training idea, obscure training objectives, lagging behind the curricular system and curriculum content with the front of the times and the development of science and technology, and the disconnection between practical education mode and engineering practice, which can't meet and satisfy the needs of modern society. Specific performance in several aspects: neglect of engineering education; lack of practical ability training; did not handle the contradiction between innovative education and traditional education; failed to meet international standards. Therefore, innovating the model of talent training and establishing a new pattern of talent training are the most important aspects of the civil engineering reform.

\section{The new model of Civil Engineering Talent Training}

Under the current situation, the talent training mode of civil engineering should embody the requirements of four aspects of "comprehensiveness", "learning type”, “internationalization" and "openness" [4-5].

\section{1) Comprehensiveness}

The ultimate goal of comprehensive education is to cultivate comprehensive talents or complex talents that meet the requirements of social development. It includes four aspects:

The comprehensive of knowledge structure. The civil engineering discipline is a subject that uses engineering theory, means and methods to solve practical engineering problems. It has a high comprehensiveness of the knowledge structure of practitioners. This also requires schools in the formulation and implementation of talent training programs, through the adjustment and improvement of curriculum settings, combined with the students' extra-curricular instructional plans, and further improve the knowledge structure of education objects, making it a more scientific and rational knowledge structure.

The comprehensive constituted by quality and ability. Civil Engineering is to train engineers with engineering and technical capabilities, so they should have good moral character, rich professional knowledge, comprehensive knowledge structure, outstanding comprehensive ability, healthy body, abundant energy, healthy psychology and with a strong sense of responsibility.

Strong comprehensive ability and analytical ability. We should be good at analyzing environment and mission objectives from multiple levels and angles and examine the accomplishment of goals and tasks. We should be good at allocating resources and interpersonal relationships and optimize the overall operation.

System thinking and analytical skills. According to the systematic thinking to deal with things, we should treat the things as a system. Only by mastering the ability of system thinking and analysis can we consciously and systematically think, analyze and act in the process of planning, organizing, leading, coordinating and controlling so as to achieve the overall goal of optimization.

\section{2) Learning type}

Learning ability refers to the ability of people to realize active and effective learning based on the existing knowledge and experience and gain new knowledge. Learning ability, as one of the components of the structure of modern talent ability, refers to the ability to actively and systematically acquire new knowledge and new technologies, including basic knowledge learning ability, self-learning ability, practical operation ability and expressive ability. Can through creative learning, cooperative learning, research learning, instructional learning, and practical learning to develop.

Learning talent has several characteristics: the desire to take the initiative to learn; to master effective learning methods; good at collecting and screening information; with strong social adaptability and plasticity; lifelong learning awareness and ability.

\section{3) Internationalization}

International talent refers to the talent with the international consciousness, mind and world-class knowledge. Their vision and ability can reach the international level. They are good at grasping opportunities and strive for initiative of high-level talents in the global competition ${ }^{[6]}$.

The primary task of training international talents is to accurately grasp the quality requirements of internationalized personnel. International talents must have the following qualities: On the basis of a strong international humanistic accomplishment, they have a strong ability of applying foreign languages and intercultural communication skills and an international perspective; having an internationalized knowledge structure and market concept; having a good sense of innovation and being more innovative Strong ability to innovate; strong information ability, the ability to use modern technology for information processing, analysis and design; national responsibility; good mental state and ability to communicate and cooperate with others.

\section{4) Openness}

Open-minded talent are able to take the initiative to face the market and social needs, with a cheerful personality, enlightened attitude, open-mindedness and vision, has a strong desire for cooperation and communication, and have strong 
communication skills, social adaptability and ability to learn complex talent.

Today's world is an open world, and its degree of openness has reached an unprecedented level. Only in this context can we educate qualified personnel to have such a strong sense of openness and ability in such a social environment maintain its own existence and achieve sustainable development. Therefore, in the course of training, we must adhere to the guidelines of "facing modernization, facing the world and the future". We consciously regard "openness" as the quality requirement of talent training and actively explore ways and measures to enhance the awareness of opening up talents and the ability to open up qualified personnel, training suitable for the requirements of the open talent.

It is the necessary prerequisite and the primary task of training open talents for accurately grasping the quality requirements of open talents. In the current situation, opening talents must have the following qualities: developing their own comprehensive quality and comprehensive ability for gearing to the needs of market and society; cheerful personality, openminded, open mind and open mind and vision; having a strong desire to cooperate and communicate with people; strong communication skills and social adaptability; strong learning ability.

"Comprehensive, Learning, Internationalization and Openness" four aspects of talent training requirements, respectively, describes one aspect of talent training mode with strong complementarity, the four have an inherent logic and interaction between. Among them, the comprehensive is the foundation, learning is the premise, open is the condition, internationalization is the goal. The comprehensiveness of the talent requirements laid the foundation of knowledge and quality and ability for the realization of the goal of internationalized personnel training. Lifelong learning consciousness and strong learning ability made it possible to achieve the goal of internationalization. The development of open talents required created the conditions for the training International talent; At the same time, the goal of internationalization provides the requirements and point out the direction for the comprehensive knowledge system for the construction and quality and ability training, as well as learning ability and open ability to exercise and improvement, this is the starting point and the destination of the three points.

In addition, in the practice of talent training, the comprehensive ability and learning ability can be improved through the knowledge of generous to the object of education and quality education for the international market and the needs of society. The consciousness of lifelong learning can be enhanced with the "facing the modernization, the world and the future”. And can cultivate qualified talents with international competitiveness.

\section{CONCLUSION}

Based on the social requirements of civil engineering professionals in our country's economic and social development, this paper explores the existing problems in the training mode of civil engineering talents in colleges and universities in our country, and puts forward a new mode of personnel training.

Through the research in this article, we can draw the following conclusions:

1)Analyzed the current status of personnel training mode in civil engineering, find out the existing problems in personnel training mode.

2)Put forward a new mode of personnel training that is "comprehensive, learning, open and internationalized" and has a strong reference to the reform of education and teaching of similar majors in our country. It has a great enlightenment on the research and practice of educational theory in the new era.

\section{REFERENCES}

[1] Qi Jia-Lian, Zhao Yading, Qi Jingyao, Fan Feng. Study on the Talent Training in Construction Fields Facing the New Industrial Revolution [J] Journal of Higher Engineering Education, 2016 (2): 26-30

[2] CHEN Xi. Main Practice and Enlightenment of Internationalization of Civil Engineering Higher Education in Singapore [J]. Higher Architectural Education, 20111,20 (4): 11-15

[3] CHEN Xiao-hu, LIU Hua-jun, QU Hua-chang. Application-oriented Personnel Training Model and Its Positioning [J] .Journal of China University of Science and Technology, 2004 (5)

[4] Zhang Dejiang. Learning to learn: basic capabilities that students must have in 21st Century [J]. Higher Education Research, 2003, 24 (6): 6972

[5] Cao Dongmei, Huang Guoxun. Exploration of the overall reform of personnel training mode [J]. China Higher Education Research, 2003 (7): 79-80

[6] CUI De-Qin, PENG Jun-Zhi. Exploring the Cultivation Pattern of Civil Engineering Specialty-oriented Talents in Applied Undergraduate Taking Jilin University of Civil Engineering and Technology as an Example [J]. Vocational and Technical Education, 2017,20 (38): 29-32 